\title{
Optimization of Bromelain Treatment pH with Wool for Antifelting and Reduced Pilling Behaviour: Objective Assessment Approach
}

\author{
Amandeep Kaur and J. N. Chakraborty \\ National Institute of Technology, Jalandhar 144 011, India \\ Correspondence should be addressed to J. N. Chakraborty; chakrabortyjn@gmail.com
}

Received 29 September 2014; Revised 31 December 2014; Accepted 31 December 2014

Academic Editor: Phillip W. Gibson

Copyright (C) 2015 A. Kaur and J. N. Chakraborty. This is an open access article distributed under the Creative Commons Attribution License, which permits unrestricted use, distribution, and reproduction in any medium, provided the original work is properly cited.

\begin{abstract}
Wool fabric possesses unique properties like resiliency, warmth, wide aesthetic qualities, and comfort. However, felting-shrinkage and pilling tendency of wool after wear and repeated launderings are its inherent limitations. Proteolytic enzymes are extensively used as biocatalysts for eco-friendly wool antifelting treatments. However, uncontrolled wool protein hydrolysis by protease may lead to excessive weight loss leading to weakening of fiber and reduction in its tensile value, which further have detrimental effect on the pilling propensity of protease treated wool during use of woolen textiles. Optimum selection of protease treatment parameters like concentration, $\mathrm{pH}$, temperature, and so forth can help in controlled reaction to achieve the desired effect, which generally involves cumbersome sampling and analysis. Optimization for $\mathrm{pH}$ of bromelain (proteolytic enzyme having activity in acidic conditions) treatment with wool has been done while aiming at the desired areawise shrinkage value, minimum weight loss, and reduced pilling by using standard methods and objective fast Fourier transformation technique for pilling evaluation specifically.
\end{abstract}

\section{Introduction}

Wool constitutes a minor yet important segment of total textile fibers produced globally in the commodity as well as luxury apparel range [1]. The remarkable properties like resiliency, cool in summer, warm in winter, and wide range of available weight and thickness makes wool suitable for traditional as well as contemporary apparels. Chemically, wool is composed mainly of proteins and lipids within heterogeneous morphological parts: the cuticle and cortex structure [2]. Cuticles are composed of overlapping cells (scales) and surround the cortex. With numerous advantages, felting arising due to scaly structure of wool is the limiting behaviour of woolen textiles that affects the consumer acceptability after repetitive wear and launderings. Many commercial treatments like chlorination, resin application, and combined methods for example, chlorine-Hercosett and so forth, have been developed to reduce wool felting as well as subsequent pilling [3]. Conventional antifelting methods have serious environment hazards, for example, release of absorbable organic halides (AOX), excess water consumption, harm to aquatic life, and so forth [4]. Use of proteolytic enzymes as biocatalysts for protein hydrolysis is a promising alternative in view of eco-friendly wool antifelting treatments. Antifelting property, improvement in fabric handle with reduction in fiber bending stiffness through structural protein degradation, reduced pilling, and improved dyeability are major claimed developments of protease treatments [511]. However, uncontrolled protein hydrolysis at the interior of fiber cortex by protease leads to excessive weight loss of wool leading to weakening of fiber and reduction in its tensile value. It has been observed that subsequent wear and launderings lead to additional abrasion or wear, and wool fabric becomes even thinner; previously formed pills break off and eventually lead to the formation of holes [12]. Hence weight loss due to proteolytic treatment may have detrimental effect on the pilling propensity of protease treated wool.

Felting tendency of wool fabric is expressed in terms of area-shrinkage \% (Woolmark specification AW-1: flat woven, pile woven, and pressed felt apparel products). According to 
this, after standard washing methods if wool fabric possesses maximum total shrinkage as 3\% each in both warp and weft directions (area shrinkage comes out to $\sim 6 \%$ ), then wool may be termed as machine washable. For pilling measurement, basically subjective, objective, and descriptive rating tests methods are applied depending on the severity of pilling after going through standard abrasion technique which may not correlate with the intended end-use [13]. Moreover balance between initial rate of pill formation and rate of loss of pills by breaking-off affects the density of pills [14]. For wool particularly, because of large number of possible variations like diet, breed, health of the sheep, climate, and so forth, physical properties like diameter, length, crimp, and their chemical composition vary. These factors in turn lead to even higher uncertainty in pilling grades obtained by replicate fabric specimen with respect to actual grades in controlled laboratory tests. Moreover, characterization of pill size from small to large and corresponding grade rating are not comparable [15]. Limitation of lesser validity of subjective pilling evaluation due to wide grade variability by judges has been also mentioned [16]. Other methods suggesting searing off pills and calculating mean pill mass, number, and total weight indicated a good correlation between weight of pills and ratings given by subjective visual assessment but had limitations like laborious, time consuming, and skill requirement for searing off pills delicately $[17,18]$. Many image processing based pilling evaluation methods are based on segmenting pills from background while considering density and spatial domains $[19,20]$.

Objective measurement of pilling evaluation has been topic of many research publications. Laser triangulation method [21], image synthesis based on the Karhunen-Loeve transform [22], digital image analysis [23], two-dimensional Gaussian fit theory to train pill template while using actual pill images for template matching [24], frequency domain analysis algorithm [25], light projection image analysis [26], noncontact three-dimensional measurement system using slit laser beam projector and CCD camera [27], wavelet reconstruction scheme using discrete wavelet transform [28], and fast Fourier transformation technique $[13,29]$ are important to mention in this regard.

Desired antifelting effect and observed weight loss is affected by number of factors like protease concentration, activity, time, temperature, $\mathrm{pH}$, rate of enzyme diffusion, and so forth during treatment. Accordingly, establishing correlated behaviour between antifelting effect, weight loss, and pilling tendency arising from weakening of wool is time consuming and cumbersome. The aim of the present study is to optimize the treatment $\mathrm{pH}$ by using objective fast Fourier transformation technique for pilling evaluation specifically and areawise shrinkage as well as weight loss of protease treated pilled wool fabric.

\section{Materials and Methods}

Woven bleached wool fabric (warp: 2/52 Nm, weft: 1/30 Nm, epi: 84 , ppi: 54, gsm: 224) was used in the study. Proteolytic enzyme bromelain was procured from Excellent Biotechnologies, Bangalore, India. Nonionic surfactant Sandoclean
PCJ (Clariant) and other analytical grade chemicals (SDFCL, India) were used. Wool samples were cut according to Martindale test specimen cutting template (38 $\mathrm{mm}$ diameter) and conditioned in standard atmosphere. Samples were used in triplicate for a specific process and were tested to calculate the standard mean and error.

2.1. Primary Optimization of Pilling Cycle Threshold. For selecting running cycle threshold, pilling test (Woolmark test method TM 196) of bleached wool samples was repeated on Martindle abrasion tester (Prolific Engineering) with respect to increasing number of cycles, that is, 30, 60, 90, 120, 150, and 180. Pilled images were taken with the help of USB Optical Microscope 800x (Micro-measure) and image analysis for average pill number and area was done by custom developed program in MATLAB software. For this, the coloured image of the samples was converted to gray and the corresponding frequency domain (by fast Fourier transformation), where spectral peaks located greater than a specified threshold, was replaced by zero (representing the high frequency repeat unit). Otsu's algorithm was used for deciding the global threshold value for every image which is then converted to binary image [30]. White part of this binary image representing the pill located on the fabric was counted in terms of "ON" pixel. Parameters related to pilling evaluation like number, area, and rating were also obtained [29].

\subsection{Treatment of Wool with Bromelain at Different $p H$ Values.} Conditioned bleached and dried wool samples were treated with fixed amount of bromelain ( $1 \%$ owf) in presence of surfactant $(0.5 \%$ owf $)$ at $60^{\circ} \mathrm{C}$ for 45 minutes in BOD incubator (Globe Tex Industries) with rotation speed of $160 \mathrm{rpm}$ while varying $\mathrm{pH}$ values from 4 to 9 (at fixed interval of 0.5 ) at $1: 30$ bath ratio. Half of treated samples were tested for areawise shrinkage (Woolmark TM31) and weight loss (\%). Remaining treated samples were abraded for 30 (optimized) cycles on abrasion tester and both subjective (Woolmark TM 96) and objective pill analyses (MATLAB software) were done. The weight loss of bromelain treated-pilled wool was calculated by subtracting the initial weight of bromelain treated wool samples (before pilling) and final weight of the pilled fabric. Microscopic evaluation of fiber surface was done with SEM (Jeol-JSM-6610LV).

\section{Results and Discussions}

3.1. Primary Optimization of Pilling Cycle Threshold. Pilled and bleached wool samples, after passing through different cycles were assessed for average pill number and pixel area in MATLAB software. Obtained trend with standard error bars is plotted in Figure 1.

It was observed that with rise in cycle till 90, pill number increased slightly and then started to decrease with little reduction in pills. Generally with increase in abrasion, fabric becomes thinner and previously formed pills break off and may be attributed to observed reduction in pill number. However, the abraded area under the pills increased which 
TABLE 1: Effect of $\mathrm{pH}$ on average areawise shrinkage (\%), weight loss (\%), pill numbers, and area of bromelain treated and bromelain treatedpilled wool.

\begin{tabular}{|c|c|c|c|c|c|c|c|}
\hline \multirow{3}{*}{$\mathrm{pH}$} & \multicolumn{2}{|c|}{ Bromelain treated } & \multicolumn{5}{|c|}{ Bromelain treated-pilled } \\
\hline & \multirow{2}{*}{$\begin{array}{c}\text { Area-wise } \\
\text { shrinkage (\%) }\end{array}$} & \multirow{2}{*}{$\begin{array}{c}\text { Average weight } \\
\text { loss }(\%)\end{array}$} & \multirow{2}{*}{$\begin{array}{l}\text { Subjective visual } \\
\text { pill rating }\left(P_{V}\right)\end{array}$} & \multicolumn{3}{|c|}{ Objective pilling evaluation } & \multirow{2}{*}{$\begin{array}{c}\text { Average weight } \\
\text { loss }(\%)\end{array}$} \\
\hline & & & & $\begin{array}{l}\text { Average pill } \\
\text { rating }\left(P_{I}\right)\end{array}$ & Average pill area & $\begin{array}{l}\text { Average pill } \\
\text { numbers }\end{array}$ & \\
\hline 4 & $\begin{array}{c}31.6 \\
(1.22)\end{array}$ & $\begin{array}{c}0.12 \\
(0.77)\end{array}$ & $\begin{array}{c}1.32 \\
(0.55)\end{array}$ & $\begin{array}{c}1.47 \\
(0.31)\end{array}$ & $\begin{array}{l}167.33 \\
(0.67)\end{array}$ & $\begin{array}{l}38.33 \\
(0.88)\end{array}$ & $\begin{array}{c}0.77 \\
(0.765)\end{array}$ \\
\hline 4.5 & $\begin{array}{c}25.6 \\
(1.22) \\
\end{array}$ & $\begin{array}{c}0.53 \\
(0.88)\end{array}$ & $\begin{array}{c}1.5 \\
(0.70)\end{array}$ & $\begin{array}{c}1.52 \\
(0.16)\end{array}$ & $\begin{array}{l}156.00 \\
(0.88)\end{array}$ & $\begin{array}{l}33.00 \\
(0.67)\end{array}$ & $\begin{array}{c}1.53 \\
(0.876)\end{array}$ \\
\hline 5 & $\begin{array}{c}22.3 \\
(0.90) \\
\end{array}$ & $\begin{array}{l}1.341 \\
(0.74) \\
\end{array}$ & $\begin{array}{c}1.82 \\
(0.82) \\
\end{array}$ & $\begin{array}{c}2.01 \\
(0.35) \\
\end{array}$ & $\begin{array}{l}121.67 \\
(1.33)\end{array}$ & $\begin{array}{l}21.00 \\
(0.88)\end{array}$ & $\begin{array}{c}2.45 \\
(0.739)\end{array}$ \\
\hline 5.5 & $\begin{array}{c}5.67 \\
(0.85) \\
\end{array}$ & $\begin{array}{l}4.710 \\
(0.35) \\
\end{array}$ & $\begin{array}{c}4.33 \\
(0.92)\end{array}$ & $\begin{array}{c}4.23 \\
(0.58)\end{array}$ & $\begin{array}{l}63.00 \\
(1.45)\end{array}$ & $\begin{array}{c}7.67 \\
(0.88)\end{array}$ & $\begin{array}{c}6.88 \\
(0.347)\end{array}$ \\
\hline 6 & $\begin{array}{c}5.1 \\
(0.62)\end{array}$ & $\begin{array}{l}5.156 \\
(0.70)\end{array}$ & $\begin{array}{c}3.92 \\
(0.69)\end{array}$ & $\begin{array}{c}3.88 \\
(0.23)\end{array}$ & $\begin{array}{l}69.67 \\
(0.58)\end{array}$ & $\begin{array}{c}7.33 \\
(0.33)\end{array}$ & $\begin{array}{c}6.94 \\
(0.70)\end{array}$ \\
\hline 6.5 & $\begin{array}{c}5.4 \\
(0.63)\end{array}$ & $\begin{array}{l}5.713 \\
(0.34)\end{array}$ & $\begin{array}{c}3.56 \\
(0.41)\end{array}$ & $\begin{array}{c}3.72 \\
(0.33)\end{array}$ & $\begin{array}{l}71.00 \\
(0.88)\end{array}$ & $\begin{array}{c}8.67 \\
(0.67)\end{array}$ & $\begin{array}{c}7.74 \\
(0.34)\end{array}$ \\
\hline 7 & $\begin{array}{c}5.9 \\
(0.82) \\
\end{array}$ & $\begin{array}{l}7.767 \\
(0.55)\end{array}$ & $\begin{array}{c}3.01 \\
(0.35) \\
\end{array}$ & $\begin{array}{c}3.23 \\
(0.15) \\
\end{array}$ & $\begin{array}{l}81.67 \\
(0.33)\end{array}$ & $\begin{array}{l}12.33 \\
(0.33)\end{array}$ & $\begin{array}{c}11.12 \\
(0.55) \\
\end{array}$ \\
\hline 7.5 & $\begin{array}{c}7.9 \\
(0.95)\end{array}$ & $\begin{array}{l}9.610 \\
(1.08)\end{array}$ & $\begin{array}{c}2.01 \\
(1.04)\end{array}$ & $\begin{array}{c}1.78 \\
(0.23)\end{array}$ & $\begin{array}{l}99.33 \\
(0.67)\end{array}$ & $\begin{array}{l}15.67 \\
(0.88)\end{array}$ & $\begin{array}{l}15.24 \\
(1.08)\end{array}$ \\
\hline 8 & $\begin{array}{c}8.8 \\
(0.85) \\
\end{array}$ & $\begin{array}{l}11.810 \\
(0.80)\end{array}$ & $\begin{array}{c}2.78 \\
(0.72) \\
\end{array}$ & $\begin{array}{c}2.9 \\
(0.30) \\
\end{array}$ & $\begin{array}{l}100.67 \\
(0.67)\end{array}$ & $\begin{array}{l}20.67 \\
(1.33)\end{array}$ & $\begin{array}{l}17.23 \\
(0.80)\end{array}$ \\
\hline 8.5 & $\begin{array}{c}18.7 \\
(1.02)\end{array}$ & $\begin{array}{l}13.63 \\
(1.48)\end{array}$ & $\begin{array}{c}2.08 \\
(0.92)\end{array}$ & $\begin{array}{c}1.9 \\
(0.36)\end{array}$ & $\begin{array}{l}133.67 \\
(0.88)\end{array}$ & $\begin{array}{l}23.67 \\
(1.33)\end{array}$ & $\begin{array}{l}19.83 \\
(1.48)\end{array}$ \\
\hline 9 & $\begin{array}{c}21.9 \\
(1.12)\end{array}$ & $\begin{array}{l}14.810 \\
(1.47)\end{array}$ & $\begin{array}{l}2.23 \\
(1.11)\end{array}$ & $\begin{array}{c}1.98 \\
(0.69)\end{array}$ & $\begin{array}{l}122.33 \\
(0.88)\end{array}$ & $\begin{array}{l}21.67 \\
(1.33)\end{array}$ & $\begin{array}{l}22.87 \\
(1.47)\end{array}$ \\
\hline
\end{tabular}

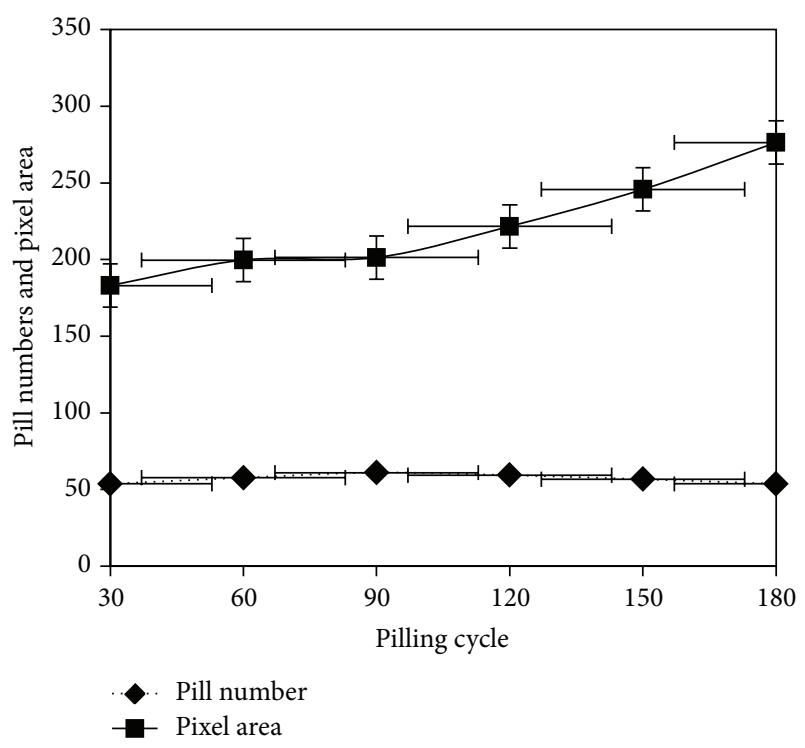

Figure 1: Average pill numbers and area for bleached wool with varying pilling cycle.

may be due to multiple splitting with increase in pilling cycles. As no significant increase in pill number was observed after the first cycle count, hence 30 cycles were assumed to be primarily responsible for the pill generation and were selected for further pills analysis.

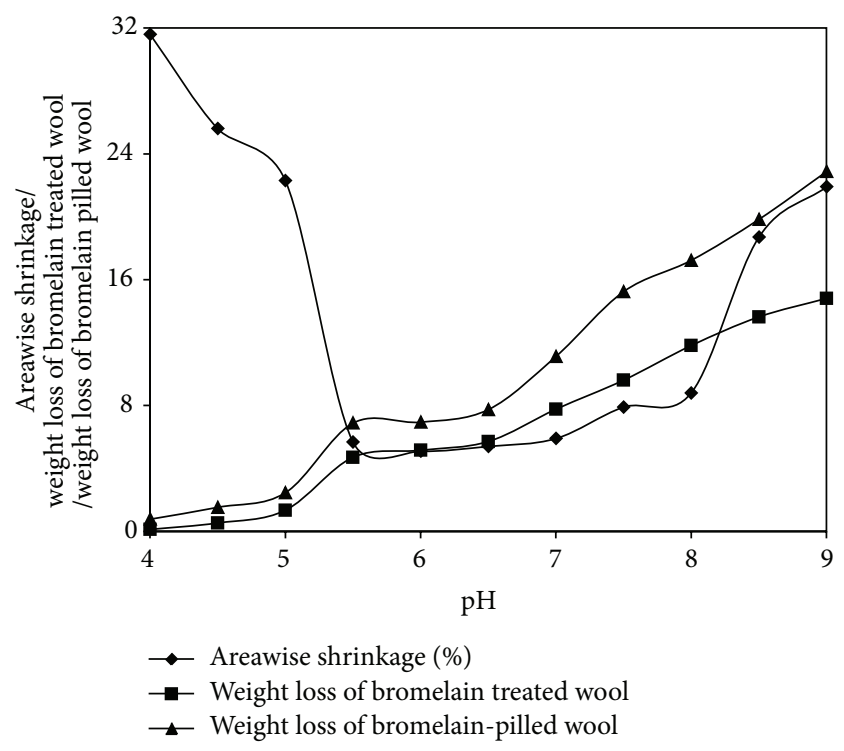

Figure 2: Variation in areawise shrinkage (\%) and weight loss (\%) with varying $\mathrm{pH}$ (standard errors of mean $<1.5$ ).

3.2. Treatment of Wool with Bromelain at Different $p H$ Values. Results obtained with respect to only bromelain as well as bromelain treated-pilled wool for shrinkage, weight loss, and pill analyses with respective standard errors of mean (data in parenthesis in respective columns) are shown in Table 1. 
Scatter plot matrix

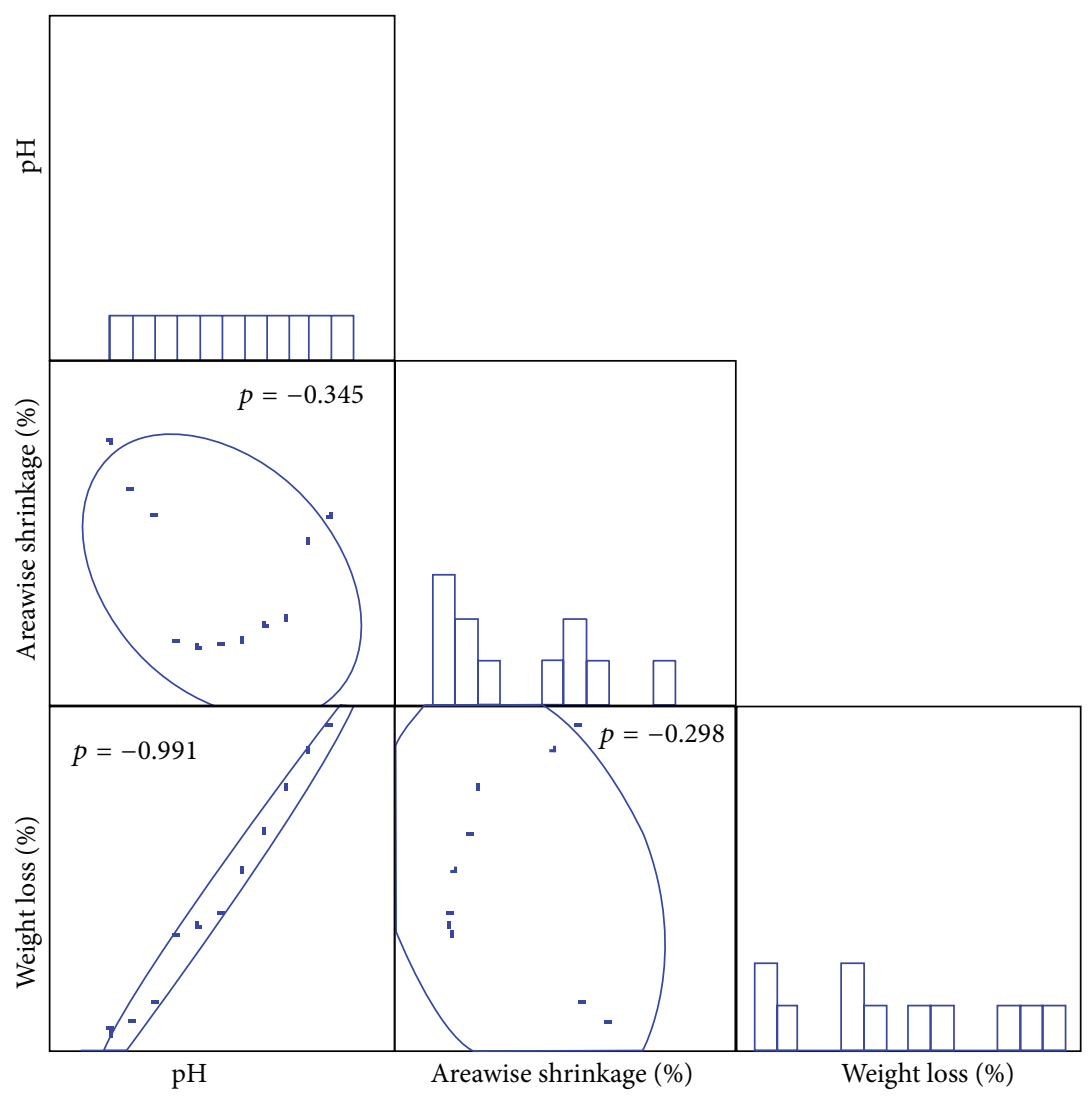

FIGURE 3: Scatter plot for pearson correlation between areawise shrinkage and weight loss with varying $\mathrm{pH}$.

3.2.1. Areawise Shrinkage (\%). To obtain desirable machine washable wool, $\mathrm{pH}$ of proteolytic treatment should provide less than $6 \%$ areawise shrinkage (Woolmark specification $\mathrm{AW}-1)$. However, among experimental range of $\mathrm{pH}$, higher values have been obtained for $\mathrm{pH} \sim 4-5.5$ (22-32\%) as well as for $\mathrm{pH} \sim 7.5-9$ (8-22\%). Only for $\mathrm{pH}$ ranging from $\sim 5.5$ to 7.0, desirable values were obtained (Figure 2).

Negative Pearson correlation $(p=-0.345)$ was observed for area shrinkage values with change in $\mathrm{pH}$. Observed high area shrinkage value in corresponding range may appear due to negligible or very substantial action of bromelain on wool leading to either ineffective or damaging effect, respectively, while affecting the weight loss too. Hence it may be assumed that relative weight loss observed during bromelain treatment may indicate either the amount of complete fiber protein hydrolysis or focused surface effect only. However, while studying the correlated behavior, only moderate negative relationship ( $p$; Pearson correlation $=-0.298$ ) was observed with in areawise shrinkage and weight loss (Figure 3). Very strong positive relationship ( $p=0.991$ ) was observed for weight loss with change in treatment $\mathrm{pH}$. Scanning electron microscopy indicating the changes induced at the fiber surface was carried out to understand the above experiential trend with varying $\mathrm{pH}$.
3.2.2. Weight Loss (\%). Proposed assumption for observed bromelain action was ascertained by assessing the trend of relative weight loss after proteolytic treatment and compared after pilling too. As observed from Figure 4, higher weight loss values were obtained for pilled samples as expected due to abrasion on fabric surface, though obtained trend was highly correlated too with changing $\mathrm{pH}(p=-0.996)$.

Considering the effect within $\mathrm{pH}$, almost similar trend has been obtained in case of bromelain treated and bromelain treated-pilled wool for $\mathrm{pH} \sim 4-6.5$, and after that the gap between the observed values widened for $\mathrm{pH} \sim 7-9$. Very less weight loss values have been obtained for $\mathrm{pH} \sim 4-4.5$ for both wool samples, suggesting very less or almost negligible action of bromelain in this $\mathrm{pH}$ range.

While comparing SEM image, scales were almost present on pilled wool treated with bromelain at $\mathrm{pH} 4.5$ (Figure 5(b)) as visible on bleached wool itself (Figure 5(a)). Only lifting of scale and wear due to pilling was found on the fiber surface. Similarly slight reduction in pill number and area was observed indicating almost similar pilling behavior in this $\mathrm{pH}$.

From pH 5.5 to 6.5 , rise in weight loss was observed that ascertained the rise in activity of bromelain in this range leading to protein hydrolysis and subsequent weight loss. 


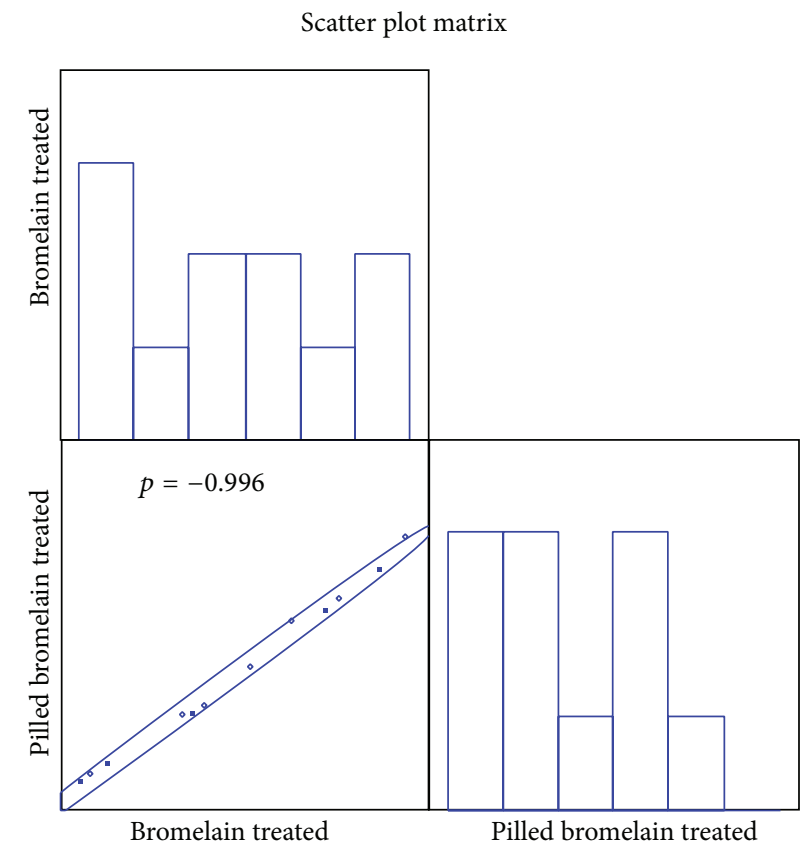

FIGURE 4: Scatter plot for Pearson correlation between weight loss of bromelain treated and bromelain treated-pilled wool with varying pH.

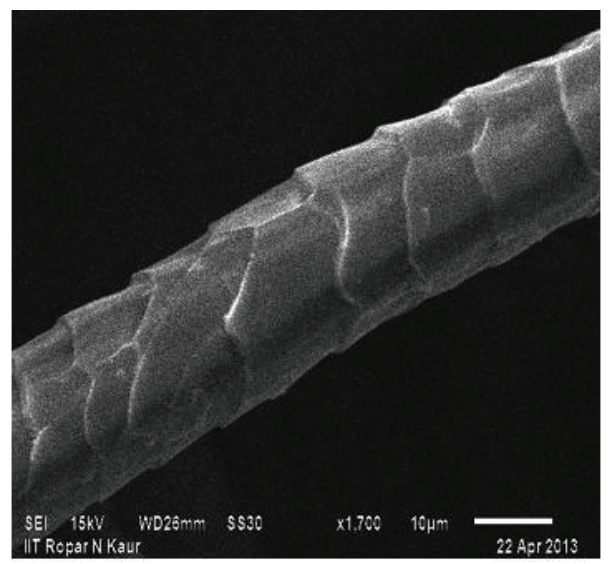

(a) Bleached wool

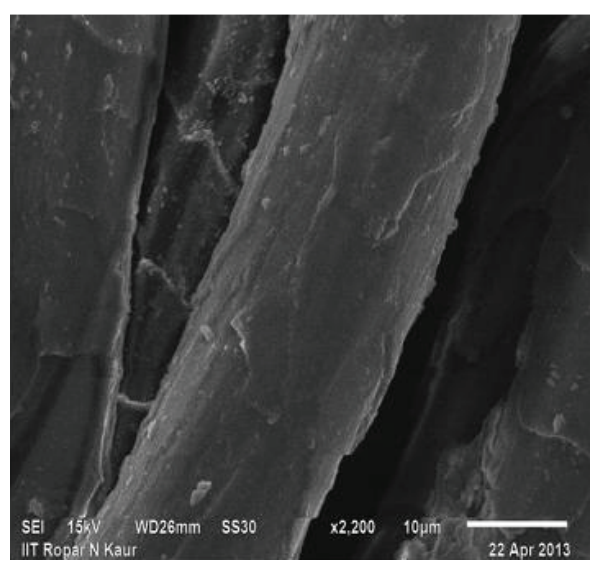

(c) Bleached wool treated with protease at $\mathrm{pH} 6.0$ and pilled

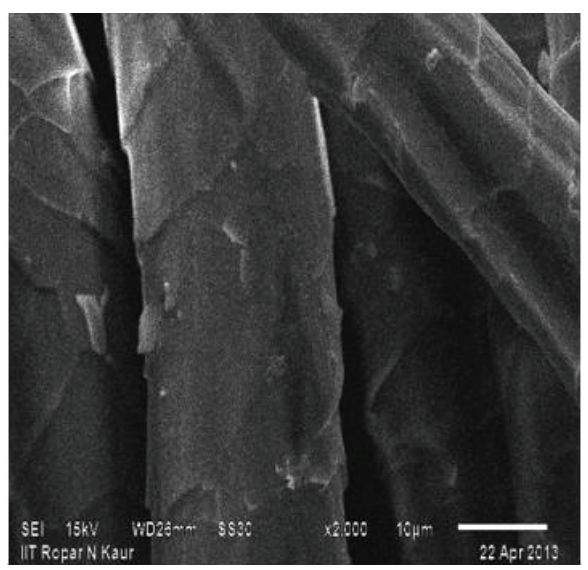

(b) Bleached wool treated with protease at $\mathrm{pH} 4.5$ and pilled

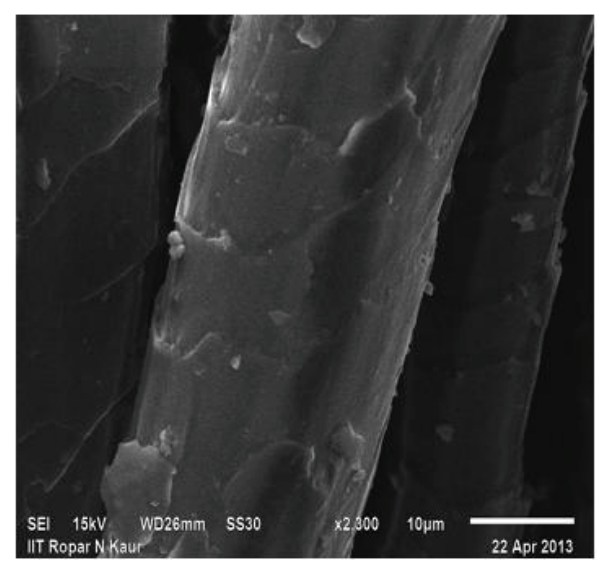

(d) Bleached wool treated with protease at $\mathrm{pH} 9.0$ and pilled

FIGURE 5: SEM (a) bleached wool, (b) bromelain treated and pilled wool at $\mathrm{pH} \sim 4.5$, (c) bromelain treated and pilled wool at $\mathrm{pH} \sim 6.0$, and (d) bromelain treated and pilled wool at $\mathrm{pH} \sim 9.0$. 


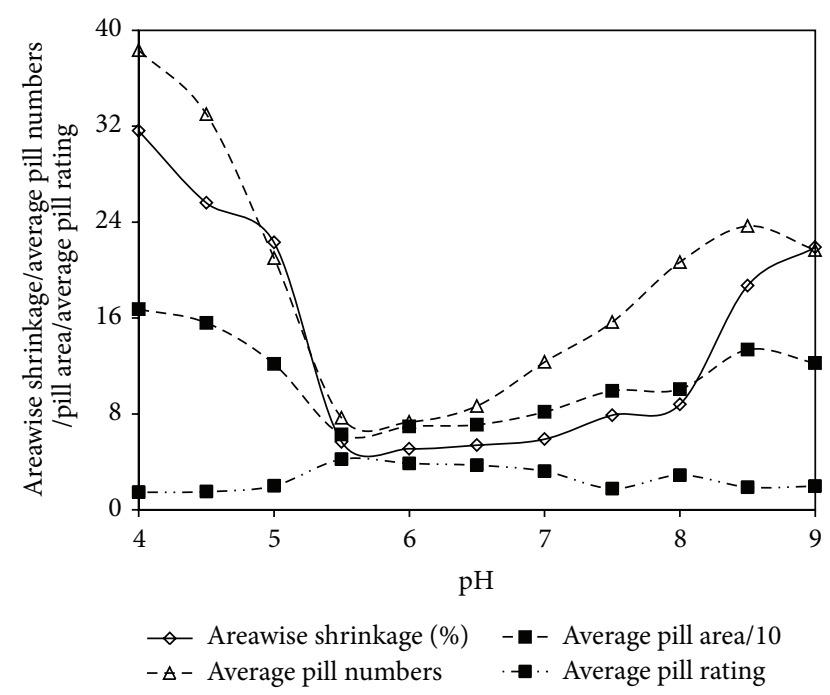

FIGURE 6: Objective pill analysis and areawise shrinkage (\%) with varying $\mathrm{pH}$ (standard errors of mean $<1.5$ ).

Fiber surface abraded due to pilling, but significant removal of scales for wool treated at $\mathrm{pH} \sim 6.0$ suggested desirable action of bromelain at this $\mathrm{pH}$ (Figure 5(c)).

High weight loss was observed for bromelain treated wool in $\mathrm{pH} \sim 7-9$ suggesting intense action of bromelain at this $\mathrm{pH}$ leading to excessive protein hydrolysis and subsequent thinning of wool fabric. However, as observed in Figure 5(d), only partially removed scales lifted on the surface of wool were found with significant wear at $\mathrm{pH} \sim 9$. Hence, it may be proposed that bromelain at this $\mathrm{pH}$ might have exhibited reduced proteolytic action; still alkaline treatment condition may have led to increased damage to wool. Inherent general stability of wool in acidic conditions as compared to alkaline also ascertained the observed trend [31]. Increase in the comparative difference between weight losses in this range also assisted the assumption as thinning or weakening of fabric may lead to higher abrasion as well as weight loss after pilling, according to observation.

In view of areawise shrinkage effect, $\mathrm{pH} \sim 5.5-7.0$ has been obtained as optimum $\mathrm{pH}$ range. But apparent weight loss and probable damage to wool beyond $\mathrm{pH} 6.5$, suggested narrowing down optimum range to $\sim 5.5$ to 6.5 .

3.2.3. Pill Analysis. Pill number and area followed " $U$ " trend while showing initial less values indicating almost similar pilling behavior at $\mathrm{pH} 4-5.5$ (Figure 6). Optimum level of pill reduction has been obtained at $\mathrm{pH} \sim 5.5-6.5$ suggesting removal of short protruding wool fibres during bromelain treatment resulting in smooth surface and generation of lesser number of pills.

Significant lifting of scales and wear was observed in all pilled samples in comparison to raw wool, though higher wear was observed for bromelain treated below as well as beyond optimum pH 5.5-6.5 (Figure 5). Observed behavior is in agreement with appearance of high number of pills and pill area for the respective $\mathrm{pH}$ range too.

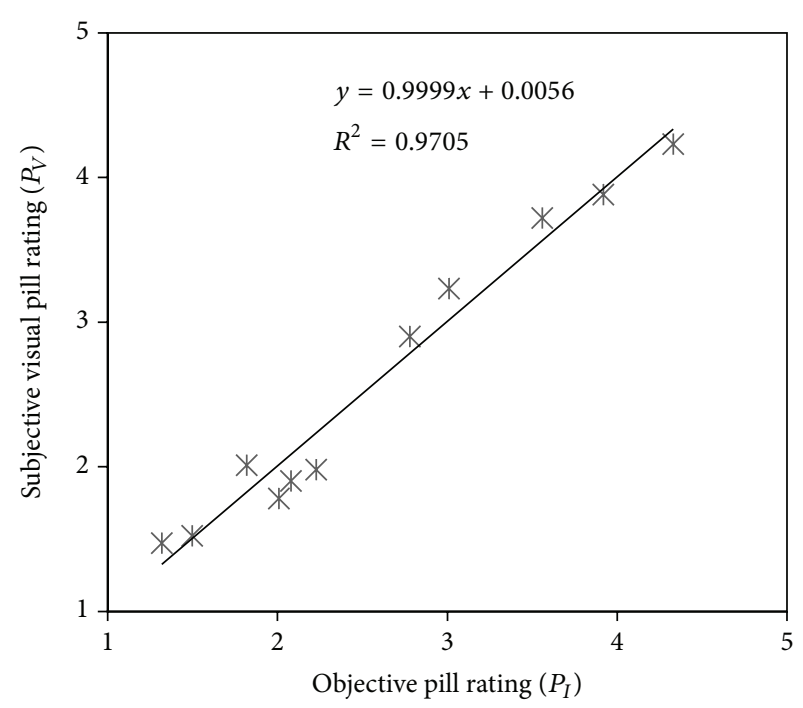

FIGURE 7: Regression trend between objective and subjective pill ratings.

For validation of objective evaluation method, regression analysis was performed comparing ratings given by the image analyser by MATLAB software with the average ratings given by expert according to standard subjective method and shown in Figure 7 (average root mean square difference $=$ 4.62 and $p$; Regression coefficient $=0.970$ ).

\section{Conclusion}

Optimized bromelain treatment with bleached wool at $\mathrm{pH} \sim$ 5.5-6.5 range resulted in desirable area shrinkage effect $(\leq 6 \%)$, weight loss $(4.7-5.7 \%)$, and optimum level of pill reduction (average pill number 7-9; pill rating 3.7-4.2). Proposed fast Fourier transform technique can be preferably applied for objective evaluation of pilling behavior of treated wool in terms of pill number, area, and rating. Strong positive correlation between standard subjective test method and objective test method ascertained the utility of proposed quicker and easier method.

\section{Conflict of Interests}

The authors declare that there is no conflict of interests regarding the publication of this paper.

\section{References}

[1] J. N. Sneddon, J. A. Lee, and G. N. Soutar, "Making sense of consumers' wool apparel preferences," Journal of the Textile Institute, vol. 103, no. 4, pp. 405-415, 2012.

[2] E. Heine and H. Höcker, "Enzyme treatments for wool and cotton," Review of Progress in Coloration and Related Topics, vol. 25, no. 1, pp. 57-70, 1995.

[3] Q. H. Chen, K. F. Au, C. W. M. Yuen, and K. W. Yeung, "Development of wool shrinkproofing, 1969-99," Textile Asia, vol. 31, no. 4, pp. 38-43, 2000. 
[4] J. G. Dominguez, P. Erra, A. de la Maza, M. R. Julia, A. Barella, and T. Shaw, "The application of the Hercosett-anionicsurfactant process to impart shrink-resistance to wool," Journal of Textile Institute, vol. 71, pp. 165-168, 1980.

[5] S. V. Chikkodi, S. Khan, and R. D. Mehta, "Effects of biofinishing on cotton/wool blended fabrics," Textile Research Journal, vol. 65 , no. 10 , pp. 564-569, 1995.

[6] H. Nolte, D. P. Bishop, and H. Höcker, "Effects of proteolytic and lipolytic enzymes on untreated and shrink-resist-treated wool," Journal of the Textile Institute, vol. 87, no. 1, pp. 212-226, 1996.

[7] D. P. Bishop, J. Shen, E. Heine, and B. Hollfelder, "The use of proteolytic enzymes to reduce wool fibre stiffness and prickle," Journal of the Textile Institute, vol. 89, no. 3, pp. 546-553, 1998.

[8] A. Riva, I. Algaba, and R. Prieto, "Dyeing kinetics of wool fabrics pretreated with a protease," Coloration Technology, vol. 118, no. 2, pp. 59-63, 2002.

[9] M. Parvinzadeh, "Effect of proteolytic enzyme on dyeing of wool with madder," Enzyme and Microbial Technology, vol. 40, no. 7, pp. 1719-1722, 2007.

[10] N. A. Ibrahim, E. A. Allam, M. B. El-Hossamy, and W. M. El-Zairy, "Enzymatic modification of cotton/wool and viscose/wool blended fabrics," Journal of Natural Fibers, vol. 5, no. 2, pp. 154-169, 2008.

[11] R. Araújo, C. Silva, R. Machado et al., "Proteolytic enzyme engineering: a tool for wool," Biomacromolecules, vol. 10, no. 6, pp. 1655-1661, 2009.

[12] W. D. Cooke and M. Goksoy, "Problem of predicting pilling performance using laboratory test methods," Melliand Textilberichte, vol. 69, pp. 250-254, 1988.

[13] B. K. Behera and T. E. M. Mohan, "Objective measurement of pilling by image processing technique," International Journal of Clothing Science and Technology, vol. 17, no. 5, pp. 279-291, 2005.

[14] J. W. S. Hearle, B. Lomas, and W. D. Cooke, Atlas of Fibre Fracture and Damage to the Textiles, Woodhead Publishing, Cambridge, UK, 1998.

[15] C. H. Hsi, R. R. Bresee, and P. A. Annis, "Characterizing fabric pilling by using image-analysis techniques. Part I: pill detection and description," Journal of the Textile Institute, vol. 89, no. 1, pp. 80-95, 1998.

[16] D. G. Neilly, "Grades of pilling," Textile Asia, vol. 3, pp. 68-69, 1990.

[17] W. Conti and E. Tassinari, "II-the numerical distribution of fibres in pills," Journal of the Textile Institute, vol. 66, no. 2, pp. 73-79, 1975.

[18] V. A. Williams, "A kinetic model for pilling of wool knitwear," Textile Research Journal, vol. 55, pp. 312-320, 1985.

[19] H. C. Abril, M. S. Millán, Y. Torres, and R. Navarro, "Automatic method based on image analysis for pilling evaluation in fabrics," Optical Engineering, vol. 37, no. 11, pp. 2937-2947, 1998.

[20] R. B. Ramgulam, J. Amirbayat, and I. Porat, "Objective assessment of fabric piling. Part I: methodology," Journal of the Textile Institute, vol. 84, no. 2, pp. 221-226, 1993.

[21] J. Amirbayat and M. J. Alagha, "The objective assessment of fabric pilling. Part II: experimental work," Journal of the Textile Institute, vol. 85, no. 3, pp. 397-401, 1994.

[22] H. C. Abril, Y. M. Torres, and M. S. Millan, "Image synthesis of pilled textiles by karhunen-Loeve transform," in 3rd Iberoamerican Optics Meeting and 6th Latin American Meeting on Optics, Lasers, and Their Applications, vol. 3572 of Proceedings of SPIE, pp. 254-258, July 1999.
[23] K. L. Jensen and J. M. Carstensen, "Fuzz and pills evaluated on knitted textiles by image analysis," Textile Research Journal, vol. 72, no. 1, pp. 34-38, 2002.

[24] B. Xin, J. Hu, and H. Yan, "Objective evaluation of fabric pilling using image analysis techniques," Textile Research Journal, vol. 72, no. 12, pp. 1057-1064, 2002.

[25] I. M. Dar, W. Mahmood, and G. Vachtsevanos, "Automated pilling detection and fuzzy classification of textile fabrics," in 5 th Machine Vision Applications in Industrial Inspection, vol. 3029 of Proceedings of SPIE, pp. 26-36, San Jose, Calif, USA, February 1997.

[26] X. Chen and X. B. Huang, "Evaluating fabric pilling with lightprojected image analysis," Textile Research Journal, vol. 74, no. 11, pp. 977-981, 2004.

[27] T. J. Kang, D. H. Cho, and S. M. Kim, "Objective evaluation of fabric pilling using stereovision," Textile Research Journal, vol. 74, no. 11, pp. 1013-1017, 2004.

[28] S. C. Kim and T. J. Kang, "Image analysis of standard pilling photographs using wavelet reconstruction," Textile Research Journal, vol. 75, no. 12, pp. 801-811, 2005.

[29] A. Khandual, A. Luximon, and A. K. Pattanayak, "Optimization of acid cellulose enzyme concentration to reduce pilling of bamboo fabric: an objective assessment approach," Fibers and Polymers, vol. 12, no. 6, pp. 816-820, 2011.

[30] N. Otsu, "A threshold selection method from gray-level histograms," IEEE Transaction of System, Man and Cybernetics, vol. 9, no. 1, pp. 62-66, 1979.

[31] A. M. Sookne and M. Harris, "Electrophoretic studies of wool," Textile Research Journal, vol. 9, no. 12, pp. 437-443, 1939. 

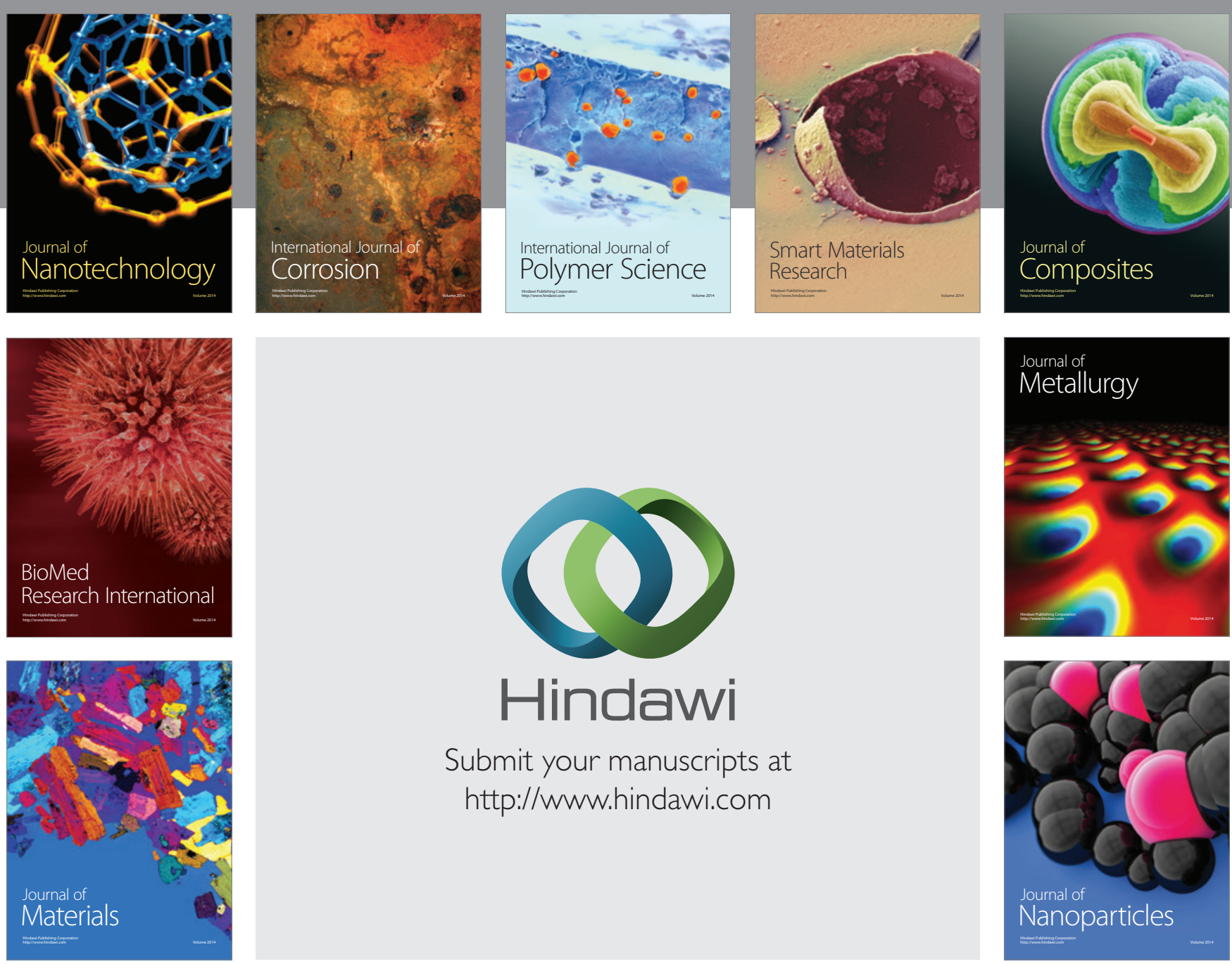

Submit your manuscripts at http://www.hindawi.com
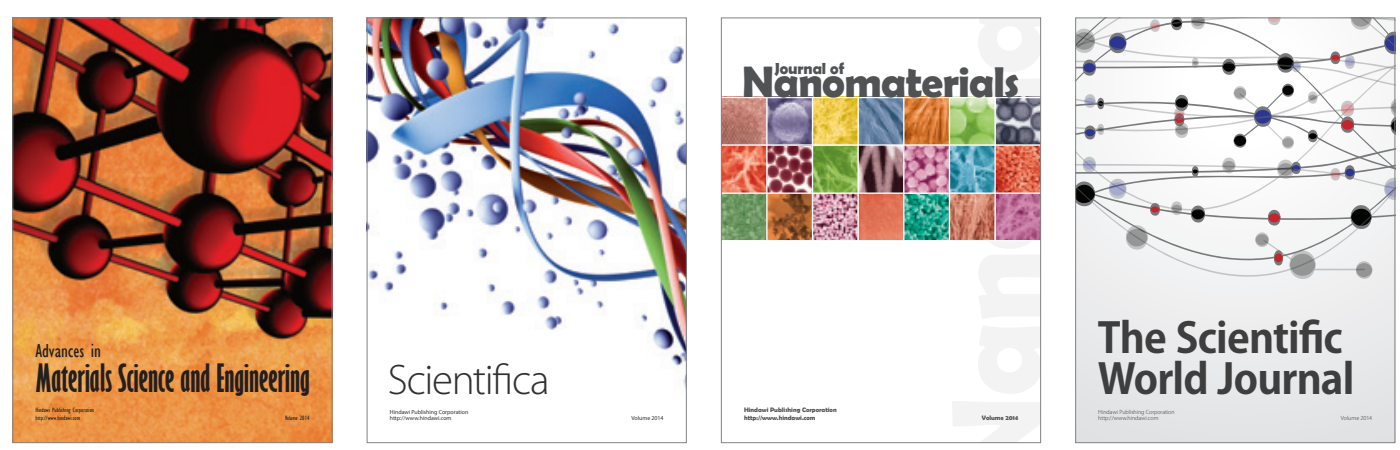

\section{The Scientific World Journal}
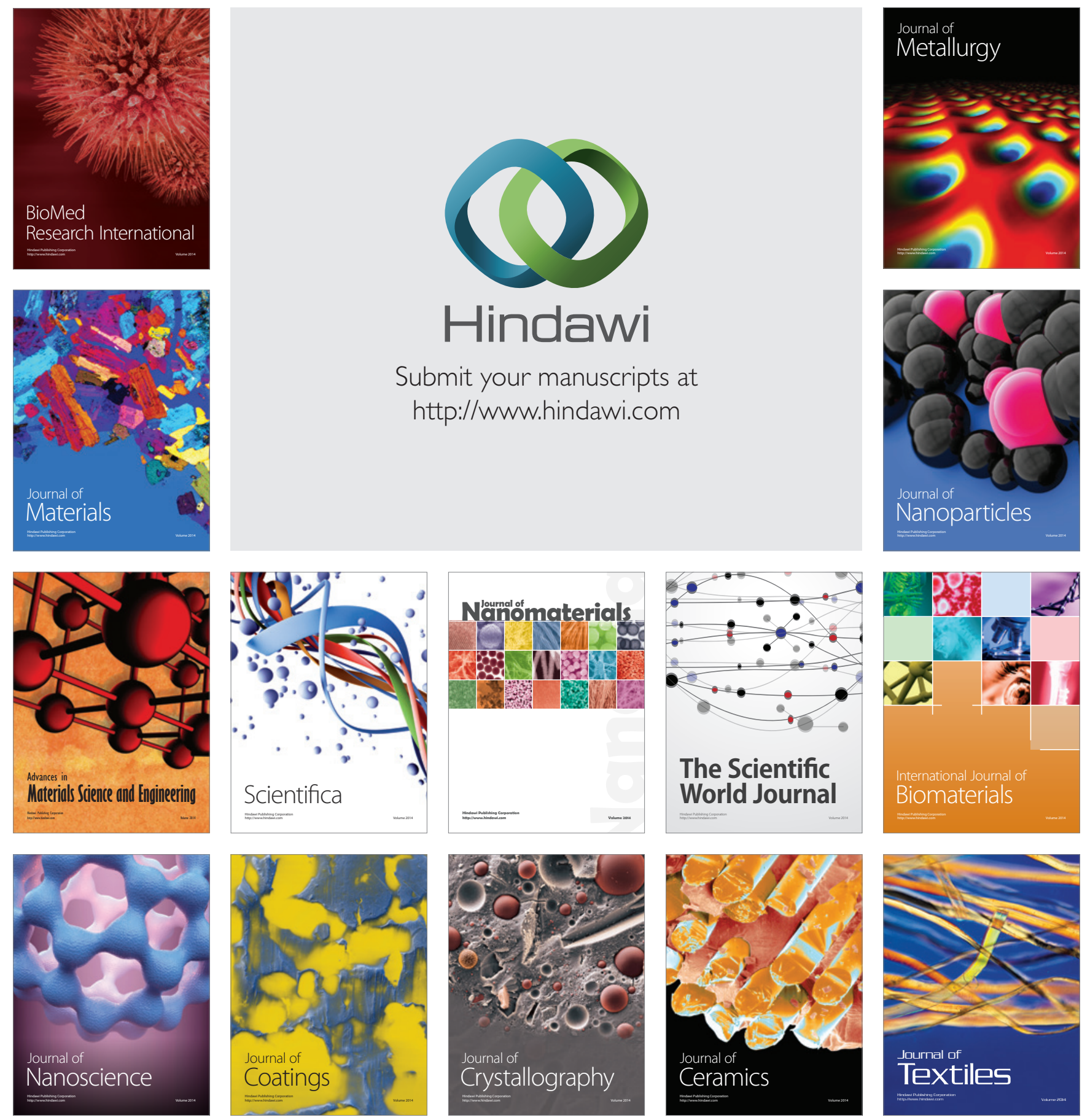